\title{
КРИТЕРІАЛЬНА ОСНОВА ДЛЯ ВИЗНАЧЕННЯ РІВНІВ СФОРМОВАНОСТІ КУЛЬТУРИ ПРОФЕСІЙНОЇ КОМУНІКАЦЇ̈ МАЙБУТНІХ ФАХІВЦІВ 3 ЕКОНОМІКИ
}

\author{
(C) Харченко I.I., 2019 \\ http://orcid.org/0000-0002-0714-2744 \\ http://doi.org/10.34142/2312-2471.2019.62.21
}

У статті описано засоби, якими можна схарактеризувати рівні сформованості компонентів культури професійної комунікації майбутніх фахівців в галузі економіки. Педагогічна теорія та практика накопичили значний досвід вирішення проблем, пов'язаних з мовою та підготовкою майбутніх економістів, тоді як бракує комплексних досліджень щзодо формування культури професійної комунікації майбутніх економістів в умовах інформаційно-освітнього середовища закладу вищзӧ освіти. У статті під культурою професійної комунікації майбутнього фахівця $з$ економіки розуміється складова його професійної культури, яка необхідна фахівцю для ефективного здійснення комунікативної діяльності, та проявляється $в$ позитивному особистісному ставленні до комунікативної взаємодї, досконалому володінні комплексом загальних і спеціальних знань, нормами мови й мовлення та вміннях їх коректного застосування у процесі передачі думки $в$ усіх видах фахового спілкування. Культура професійної комунікації майбутніх економістів має нетривіальну структуру $i$ розглядається як єдність аксіологічного (цінності та мотиви професійного спілкування), теоретичного (уявлення майбутніх економістів про систему мови та знання мови та мовлення) компонентів, а також це - професійна термінологія (вміння користуватися економічною термінологією), економічна мова для професійних цілей та розуміння мовлення інших), процесуальний (здатність використовувати мову як засіб спілкування в різних професійних ситуаціях), особистий (здатність розмірковувати про професійне спілкування) складники. Розроблено відповідно п'ять критерїв: изіннісно-мотиваційний, когнітивний, словесно-операційний, поведінково-комунікативний та рефлексивний. Їх показниками $\epsilon$ : загальнокультурна обізнаність, граматична обізнаність, лексична обізнаність, інформаџійна обізнаність, здатність оперувати термінами, перцуептивні та мовленнєві здібності, навички електронного спілкування, професійні та творчі навички, вольові якості, здатність до самоочінки. Рівнями сформованості культури професійної комунікації майбутніх фахівців в галузі економіки визначено досконалий, високий, середній, базовий.

Ключові слова: професійна підготовка, майбутні фахівціі в галузі економіки, культура професійної комунікації, критерії, показники, рівні. 


\section{Kharchenko I.I. Criteria, Indicators and Levels of Culture Formation of Professional Communication for Future Economics}

The article describes the tools that can be used to characterize the levels of formation of culture components of professional communication for future specialists in economics. Pedagogical theory and practice have accumulated considerable the experience in solving problems related to language and future economists training, while there is a lack of comprehensive research on culture formation of professional communication of future economists in the information and educational environment. The professional communication culture of future economists has a non-trivial structure and is considered as a unity of axiological (values and motives of professional communication), theoretical (ideas of future economists about the system of language and knowledge of language and speech) components, professional terminology as well (ability to use economic terminology, economic language for professional purposes and to understand the speech of others), procedural (ability to use language as a means of communication in various professional situations), personal (ability to reflect on professional communication) components too. Five criteria have been developed, respectively: value-motivational, cognitive, verbal-operational, behavioral-communicative, and reflexive. Their indicators are: general cultural awareness, grammatical awareness, lexical awareness, IT awareness, ability to operate with terms, perceptual and speech ability, e-communication skills, professional and creative skills, volitional qualities, ability to self-esteem. The tasks aimed at identifying the state of culture formation of professional communication of future specialists in economics at the present stage are composed of the criteria, indicators taking into account that it allows to assess objectively the real levels of formation of the diagnosed culture for professional communication (perfect, high, average, basic levels).

Key words: professional training, future specialists in economics, culture of professional communication, criteria, indicators, levels.

Постановка проблеми. У сучасному суспільстві, де спостерігаються тенденції віртуалізації усіх сфер життєдіяльності людини, науковці відзначають важливість якісної комунікації в соціумі, що актуалізує проблему формування у особи культури комунікації як особистісної, так i професійної. Проте володіючи лише нормами літературної мови, майбутній фахівець не завжди може досягти бажаних результатів співпраці, оскільки в процесі перемовин у фаховому середовищі потребуватиме розуміння специфічних термінів, професійного сленгу, спілкування усталеними для галузі каналами зв'язку.

3 огляду на підвищені вимоги сучасного ринку праці до економістів, що зумовлені активним розвитком науково-технічного прогресу, рівнем економічного розвитку країни, темпами інфляції, конкуренцією на світовому ринку, політичною нестабільністю та соціокультурними факторами, особливого значення набуває культура професійної комунікації фахівця з економіки як складова його загальної професійної культури. 
Аналіз останніх досліджень і публікацій. Концептуальні засади формування культури професійної комунікації майбутніх фахівців грунтуються на положеннях міжнародних («Меморандум освіти протягом життя», 2000 р.; Загальноєвропейські рекомендації 3 мовної освіти, 2003 р.) та загальнодержавних документів (Закони України «Про освіту», 2017 р., «Про вищу освіту», 2014 р., «Про професійний розвиток працівників», 2012 р., Указ Президента України «Про невідкладні заходи щодо зміцнення державного статусу української мови та сприяння створенню єдиного культурного простору України», 2018 р. Національна стратегія розвитку освіти в Україні на 20122021 роки, Концепція освіти дорослих в Україні, 2011 р., Концепція розвитку економічної освіти в Україні (2003) тощо).

Для вирішення проблеми формування культури професійної комунікації фахівців з економіки в межах їхньої професійної підготовки важливими $\epsilon$ наукові праці, в яких обгрунтовано положення сучасної філософії і методології професійної освіти (В. Андрущенко, І. Зязюн, В. Кремень та ін.), освіти дорослих (В. Лозовецька, Л. Лук'янова, Н. Ничкало та ін.); окреслено підходи до професійного розвитку особистості: компетентнісний (Н. Бібік, О. Дубасенюк, О. Савченко та ін.); особистісно орієнтований (І. Бех, Л. Хомич та ін.), акмеологічний (А. Деркач, Н.Сидорчук, В. Сидоренко та ін.), культурологічний (О. Асмолов, М. Бастун, Г.Васянович, О. Лобова, О. Отич та ін.); проаналізовано сутність мовної, мовленнєвої, мовно-мовленнєвої компетентностей (М. Вашуленко, О. Горошкіна, Л. Мацько, О. Семеног та ін.) $[1 ; 2 ; 3 ; 5]$.

Виділення невирішених раніше частин загальної проблеми. Узагальнення результатів наукових досліджень дає підстави стверджувати, що у педагогічній теорії й практиці накопичено значний досвід у вирішенні проблем, пов'язаних з мовною і професійною підготовкою майбутніх фахівців 3 економіки, використанням інформаційних ресурсів закладу освіти для іiі організації та супроводу, водночас у вітчизняній професійній освіті бракує комплексних досліджень, присвячених проблемі формування культури професійної комунікації майбутніх фахівців 3 економіки в умовах інформаційно-освітнього середовища ЗВО.

Мета статті - визначити критерії та показники, за якими можна схарактеризувати рівні сформованості компонентів культури професійної комунікації майбутніх фахівців з економіки.

Виклад основного матеріалу. Культура професійної комунікації майбутнього фахівця 3 економіки - це складова професійної культури, яка необхідна фахівцю $з$ економіки для ефективного здійснення комунікативної діяльності, та проявляється в позитивному особистісному ставленні до комунікативної взаємодії, досконалому володінні комплексом загальних i спеціальних знань, нормами мови й мовлення та вміннях їх коректного застосування у процесі передачі думки в усіх видах фахового спілкування [7; $8]$. 
Культура професійної комунікації майбутніх фахівців 3 економіки має нетривіальну структуру [4; 6] і розглядається як єдність аксіологічного (ціннісні установки та мотиви професійної комунікації), теоретичного (уявлення майбутніх економістів про систему мови та знання правил мови $\mathrm{i}$ мовлення), професійно-термінологічного (уміння користуватися економічною терміно-лексикою, економічною мовою у професійних цілях та для розуміння мовлення інших), процедурного (здатність користуватися мовою як засобом спілкування у різних професійних ситуаціях), особистісного (здатність до рефлексії професійної комунікації) компонентів.

Оскільки нами схарактеризовано п'ять складових культури професійної комунікації, то розроблено відповідно п'ять критеріїв - ціннісно-мотиваційний, когнітивний, вербально-операційний, поведінково-комунікативний, рефлексивний. Можемо узагальнити виокремлені критерії та показники сформованості культури професійної комунікації майбутніх фахівців 3 економіки у таблиці 1.

Таблиия 1

\section{КРИТЕРІЇ ТА ПОКАЗНИКИ СФОРМОВАНОСТІ КУЛЬТУРИ ПРОФЕСІЙНОЇ КОМУНІКАЦЇ̈ МАЙБУТНІХ ФАХІВЦІВ 3 ЕКОНОМІКИ}

\begin{tabular}{|c|c|c|}
\hline $\begin{array}{c}\text { Компоненти } \\
\text { КПК } \\
\end{array}$ & $\begin{array}{c}\text { Критерії } \\
\text { сформованості КПК }\end{array}$ & Показники сформованості КПК \\
\hline Аксіологічний & Ціннісно-мотиваційний & Загальнокультурна обізнаність \\
\hline \multirow{3}{*}{ Теоретичний } & \multirow{3}{*}{ Когнітивний } & Граматична обізнаність \\
\hline & & Лексична обізнаність \\
\hline & & IT-обізнаність \\
\hline \multirow{2}{*}{$\begin{array}{l}\text { Професійно- } \\
\text { термінологічний }\end{array}$} & \multirow{2}{*}{ Вербально-операційний } & $\begin{array}{c}\text { Перцептивно-мовленнєва } \\
\text { здатність }\end{array}$ \\
\hline & & Здатність оперувати термінами \\
\hline \multirow{2}{*}{ Процедурний } & \multirow{2}{*}{$\begin{array}{c}\text { Поведінково- } \\
\text { комунікативний }\end{array}$} & Професійно-креативні вміння \\
\hline & & Уміння е-комунікації \\
\hline \multirow{2}{*}{ Особистісна } & \multirow{2}{*}{ Рефлексивний } & Вольові якості \\
\hline & & Здатність до самооцінки \\
\hline
\end{tabular}

Відповідно до визначених критеріїв схарактеризуємо рівні сформованості культури професійної комунікації майбутніх фахівців з економіки: досконалий, високий, середній, базовий. Опишемо рівні.

Досконалий рівень. Студенти цього рівня володіють грунтовними знаннями про фонологічні, лексичні, граматичні системи мови; обізнані 3 функціональними стилями та жанрами української мови, стилістичними прийомами й експресивними засобами їх актуалізації; вміють розпізнавати й адекватно використовувати економічну термінологію, фразеологію, реалії та іншу засвоєну лексику в професійній сферах відповідно до правил граматичної будови мови, комунікативної ситуації; коректно вимовляють мовні одиниці. 
Майбутні фахівці 3 економіки уміють продуктивно безконфліктно співпрацювати 3 партнерами в гетерогенних групах; володіють грунтовними знаннями та уміють перетворювати фонові знання у текст, свідомо застосовують інтегративні знання про лінгвістичні та невербальні засоби побудови і презентації підготовленого та непідготовленого усного і писемного монологічного i діалогічного мовлення; легко розуміють на слух комунікативний намір та адекватно реагують на репліки.

Зміст, логічна побудова i мовне оформлення мовлення студентів відповідають стилістичним нормам, вирізняється лексичним багатством та різноманітністю граматичних форм і конструкцій. Проявляють творчість та оригінальність у розв'язанні професійних завдань, постійно перебувають у пошуках нових та нестандартних методів, впевнено обгрунтовуючи й відстоюючи власні погляди, демонструючи знання фахових термінів. Це сприяє постійному налагодженню комунікативних зв'язків і відносин i забезпечує відповідний успіх у діловому спілкуванні.

Високий рівень. Студенти цього рівня володіють знаннями про фонологічні, лексичні, граматичні системи мови; обізнані з функціональними стилями та жанрами, стилістичними прийомами й засобами їх актуалізації, але припускаються незначних неточностей, поодинокі орфографічні та орфоепічні огріхи, поодинокі помилки на морфологічному (використання деяких часток) i синтаксичному рівнях. Майбутні фахівці з економіки уміють безконфліктно співпрацювати з партнерами в соціально гетерогенних групах.

Студенти переважно застосовують інтегративні знання про лінгвістичні та невербальні засоби побудови i презентації підготовленого та непідготовленого усного і писемного монологічного і діалогічного мовлення, однак можуть допустити окремі відхилення від формату комунікативної ситуації; без значних зусиль розуміють головну думку, основні ідеї, загальний зміст матеріалу, комунікативний намір.

Студенти мають фундаментальні знання економічної термінології, проте допускають поодинокі неточності під час використання іії під час налагодження комунікативних відносин та під час оформлення ділової документації. Студенти вміють оцінювати власну роботу, прагнуть до одержання нових знань (зокрема засвоєння нової термінології), проте інколи потребують консультацій та підтримки викладача. Проявляють достатній рівень креативності, впевнено висловлюють власні погляди, демонструють знання фахових термінів. Мають успіх у діловому спілкуванні.

Середній рівень. Студенти цього рівня недостатньо володіють знаннями про фонологічні, лексичні, граматичні системи мови; допускають неточності у визначенні лінгвістичних явищ й функціональних стилів; обізнані 3 деякими стилістичними прийомами текстів різної жанрово-стильової спрямованості; проте припускаються неправильного вживання або сплутування синонімів, антонімів, фразеологічних одиниць, не розмежування омонімії і полісемії, орфографічних огріхів; припускаються непоодиноких помилок у використанні часток, побудові складнопідрядних речень; порушують правила орфоепії за 
тоновим наголосом. У майбутніх економістів не сформовано інтегративні знання про лінгвістичні та невербальні засоби побудови і презентації підготовленого та непідготовленого усного i писемного монологічного i діалогічного мовлення; студенти допускають неточності та відхилення від формату комунікативної ситуації.

Студенти відчувають значні труднощі при користуванні довідковою та спеціальною літературою, програмами 3 повнотекстового пошуку під час пошуку необхідної інформації; невдало опрацьовують термінологічні бази даних; ігнорують наявність типових текстових помилок, не корегують їх. Студенти невпевнено орієнтуються та діють в професійно-спрямованій ситуації. Комунікативні дії почасти позбавлені самостійності і креативності, наявні окремі недоліки в аналізі тексту. Середній рівень сформованості навчальних досягнень студентів.

Базовий рівень. Студенти цього рівня виявляють незнання фонологічної, лексичної, граматичної системи мови; не обізнані із стилістичними прийомами й експресивними засобами актуалізації текстів різної жанрово-стильової спрямованості; не розпізнають i не використовують основну галузеву термінологію в академічній та професійній сферах; припускаються неправильного вживання і сплутування синонімів, антонімів, фразеологічних одиниць, нерозмежування омонімії і полісемії, орфографічних огріхів, порушують правила граматики й орфоепії.

Студенти відхиляються від формату комунікативної ситуації; припускають багато фактичних неточностей під час тлумачення загального змісту економічного матеріалу; порушують зміст, логічну побудову, жанровостильові i мовні норми оформлення підготовлених усних i писемних висловлювань. Лексико-граматична будова мовлення бідна та одноманітна; наявні грубі помилки різного характеру. Характерна шаблонність дій, що підкріплюється позицією «і так добре». Більшість показників не мають достатньої сформованості та вираження.

Такі студенти безініціативні, все роблять під натиском та без зацікавленості; не мають бажання продовжувати вивчення професійної термінології, задовольняючись досягнутим рівнем; досить рідко використовують фахові визначення в професійному мовленні; здатні до обробки невеликих за обсягом текстів професійного спрямування, а оформлення ділової документації здійснюється шаблонно; мають низький рівень адаптації професійної термінології. Відсутнє прагнення до спілкування. Переважають зовнішні мотиви вибору професії.

Висновки. Отже, визначені критерії та їх показники-маркери покладено в основу характеристики рівнів сформованості культури професійної комунікації майбутніх фахівців 3 економіки. Завдання, спрямовані на виявлення стану сформованості культури професійної комунікації майбутніх фахівців 3 економіки на сучасному етапі у 3ВО, складено 3 їх (критеріїв, показників) урахуванням, що надає змогу об'єктивно оцінити реальні рівні сформованості 
діагностованої культури професійної комунікації та визначити зміст і структуру експериментальної діяльності.

Перспективи подальших досліджень. Наукове дослідження не вичерпує всі аспекти проблеми формування культури професійної комунікації майбутніх фахівців з економіки в умовах інформаційно-освітнього середовища ЗВО й засвідчує необхідність їі подальшої розробки за такими перспективними напрямами: розвиток культури професійної комунікації майбутніх фахівців 3 економіки у процесі виробничої практики, в умовах неформальної освіти, на засадах самоосвітньої діяльності.

\section{Jimepamypa}

1. Артюшина М. В. Психолого-педагогічні засади підготовки студентів економічної спеціальності до інноваційної діяльності : дис. ... докт. пед. наук : 13.00.04. Київ, 2011. 534 с.

2. Барановська Л. В. Теоретико-методичні основи навчання професійного спілкування студентів вищого аграрного навчального закладу : дис. ... д-ра наук: 13.00.04 - теорія i методика професійної освіти / Національний педагогічний університет імені М.П. Драгоманова, Київ, 2005. 438 с.

3. Биков В. Ю. Теоретико-методологічні засади моделювання навчального середовища сучасних педагогічних систем / Інформаційні технології і засоби навчання: зб. наук. праць / [за ред. В. Ю. Бикова. Ю. О. Жука] / Інститут засобів навчання АПН України. Київ : Атіка. 2005. С. 5 - 15.

4. Вікторова Л. В. Формування професійно-термінологічної компетентності студентів вищих аграрних навчальних закладів у фаховій підготовці : дис.. канд.. пед.. наук: 13.00.04. Київ, 2009. 257 с.

5. Горіна Ж. Д. Розвиток українського розмовного мовлення студентів національних груп нефілологічних факультетів вищих навчальних закладів південного регіону України: дис. ... канд. пед. наук: 13.00.02. Одеса, 2001. 268 c.

6. Дроздова І. П. Наукові основи формування українського професійного мовлення студентів нефілологічних факультетів ВНЗ : монографія. Харків : ХНАМГ, 2010. 319 с.

7. Руденко Л. А. Формування комунікативної культури майбутніх фахівців сфери обслуговування у професійно-технічних навчальних закладах : монографія. Львів : Піраміда, 2015. 342 с.

8. Харченко I.I. Культура професійної комунікації майбутніх фахівців 3 економіки в умовах інформаційно-освітнього середовища закладу вищої освіти: монографія. Суми, 2019. 354 с.

\section{References}

1. Artyushina, M.V. (2011). Psychological and pedagogical principles of preparation of students of economic specialty for innovation: dis. ... dr. ped. science: 13.00.04. Kyiv.

2. Baranovska, L.V. (2005). Theoretical and methodical bases of teaching 
professional communication of students of higher agrarian educational institution: dis ... doctor of sciences: 13.00.04 - theory and methods of professional education / National Pedagogical University named after MP Drahomanova, Kyiv.

3. Bykov, V.Y. (2005). Theoretical and methodological principles of modeling the learning environment of modern pedagogical systems / Information technology and teaching aids: collection. Science. works / [ed. V. Yu. Bykova. Yu. O. Zhuk / Institute of Teaching Aids of the Academy of Pedagogical Sciences of Ukraine. Kyiv: Attica.

4. Viktorova, L.V. (2009). Formation of professional-terminological competence of students of higher agrarian educational institutions in professional training: dis ... candidate of pedagogical sciences: 13.00.04. Kyiv.

5. Gorina, J.D. (2001). Development of Ukrainian conversational speech of students of national groups of non-philological faculties of higher educational institutions of the southern region of Ukraine: dis. ... cand. ped. science: 13.00.02. Odessa.

6. Drozdova, I.P. (2010). Scientific bases of formation of the Ukrainian professional speech of students of non-philological faculties of high schools: monograph. Kharkiv: KNAMG.

7. Rudenko, L.A. (2015). Formation of communicative culture of future specialists in the field of service in vocational schools: monograph. Lviv: Pyramid.

8. Kharchenko, I.I. (2019). The culture of professional communication of future specialists in economics in the information and educational environment of higher education: a monograph. Sumy. 